\title{
Impact of forest management on threatened epiphytic macrolichens: evidence from a Mediterranean mixed oak forest (Italy)
}

\author{
Luca Paoli ${ }^{(1)}$, \\ Renato Benesperi ${ }^{(2)}$, \\ Zuzana Fačkovcová (3), \\ Juri Nascimbene ${ }^{(4)}$, \\ Sonia Ravera ${ }^{(5)}$, \\ Marco Marchetti ${ }^{(5)}$, \\ Barbara Anselmi ${ }^{(6)}$, \\ Marco Landi ${ }^{(7)}$, \\ Sara Landi ${ }^{(8)}$, \\ Elisabetta Bianchi ${ }^{(2)}$, \\ Luca Di Nuzzo(2), \\ Anna Lackovičová (3), \\ Andrea Vannini ${ }^{(9)}$, \\ Stefano Loppi ${ }^{(9)}$, \\ Anna Guttová (3)
}

\begin{abstract}
Forest management practices may heavily affect epiphytic cryptogams. This study was conceived in March 2016, as soon as we were informed about an authorized logging for timber within a Mediterranean mixed oak forest in Tuscany (central Italy), which threatened a large population of the forest macrolichen Lobaria pulmonaria (L.) Hoffm., composed of hundreds of fertile thalli. Lobaria pulmonaria is often used as an ecological indicator of high quality habitats hosting rare lichens, and in general, cryptogams worthy of conservation. The species has suffered a general decline throughout Europe as a consequence of air pollution and intensive forest management, and currently it is red-listed in several countries, where it is considered also as a "flag species". We estimated that $40 \%$ of the lichen biomass $\left(8.5-12.3 \mathrm{~kg} \mathrm{ha}^{-1}\right)$ has been lost due to logging operations (in the core area, up to $1.8 \mathrm{~kg}$ every $100 \mathrm{~m}^{2}$ ), in particular large and fertile thalli. One year after the conclusion of logging operations, the analysis of chlorophyll fluorescence emission (indicator of the photosynthetic performance of the lichen photobionts), revealed a significant reduction of the vitality of the thalli on retained-isolated trees. The article provides issues for conservation in Mediterranean oak forests and outlines the outmost importance of ensuring the safeguard of forest ecosystems hosting fertile populations of this model species, especially in the case of unprotected forests.
\end{abstract}

Keywords: Biomass Loss, Chlorophyll Fluorescence, Flag Species, Legal Protection, Lobaria pulmonaria, Red Lists

forest lichen Lobaria pulmonaria Hoffm., which has suffered a general decline throughout Europe as a consequence of global change and forestry (Otálora et al. 2011, Nascimbene et al. 2016), whose effects are expected to be further exacerbated by climate change (Nascimbene et al. 2016). Its occurrence and abundance are used as indicators of forest ecological con-
(1) Department of Biology, University of Pisa, v. Ghini 13, 56126, Pisa (Italy); (2) Department of Biology, University of Florence, v. La Pira 4, I-50121, Florence (Italy); (3) Plant Science and Biodiversity Centre, Slovak Academy of Sciences, Dúbravská cesta 9, SK-84523 Bratislava (Slovakia); (4) Department of Biological, Geological and Environmental Sciences, University of Bologna, v. Irnerio 42, I-40126 Bologna (Italy); (5) University of Molise, Campobasso (Italy); (6) Associazione Culturale di Murlo, p.zza Cattedrale, I-53016 Murlo, Siena (Italy); (7) Reparto Carabinieri per la Biodiversità di Siena, Loc. Il Braccio 4, I-53100 (Italy); (8) Department of Natural and Land Sciences, University of Sassari, Loc. Piandanna, I-07100 Sassari (Italy); (9) Department of Life Science, University of Siena, v. Mattioli 4, I-53100 Siena (Italy)

@ Luca Paoli (luca.paoli@unipi.it)

Received: Aug 20, 2018 - Accepted: Apr 28, 2019

Citation: Paoli L, Benesperi R, Fačkovcová Z, Nascimbene J, Ravera S, Marchetti M, Anselmi B, Landi M, Landi S, Bianchi E, Di Nuzzo L, Lackovičová A, Vannini A, Loppi S, Guttová A (2019). Impact of forest management on threatened epiphytic macrolichens: evidence from a Mediterranean mixed oak forest (Italy). iForest 12: 383-388. - doi: 10.3832/ifor2951-012 [online 2019-07-12]

Communicated by: Rodolfo Picchio tinuity (Rose 1976, Nadyeina et al. 2014) and for mapping forest sites worthy of conservation (Campbell \& Fredeen 2004, Bergamini et al. 2005, Nascimbene et al. 2010, Brunialti et al. 2015). Currently, L. pulmonaria is a red-listed species in several European countries (Scheidegger et al. 2002, Krause et al. 2017).

Forest management is associated with forest fragmentation and trees exploitation that cause a complete break in the availability of the primary habitat for epiphytic lichens (Otálora et al. 2011, Whittet \& Ellis 2013), strongly impacting the most sensitive species such as L. pulmonaria, whose distribution is limited by its dispersal capacity and the presence of suitable (high-quality) habitats (Ockinger et al. 2005, Jüriado et al. 2011).

The negative effects of silviculture on $L$. pulmonaria were early reported at the beginning of the last century (Lettau 1912) and outstanding works summarize the interactions between different forest management practices and $L$. pulmonaria populations (Scheidegger \& Werth 2009, Aragón et al. 2010, Nascimbene et al. 2013a, Brunialti et al. 2015). Intensive forest management may threaten L. pulmonaria, and in general sensitive forest lichens, causing habitat fragmentation, degradation and loss, that impact local populations structure, size and dynamics (Scheidegger \& Werth 2009, Benesperi et al. 2018). Log- 
ging may deplete species with poor dispersal ability (such as L. pulmonaria), which would remain restricted to the non-disturbed parts of the forest landscapes (Scheidegger \& Werth 2009). Moreover, after logging epiphytic lichens are exposed to a sudden increase of sun irradiance and dry conditions, which, if in excess of the ecological range, may injure photosynthetic performances, and hence thallus vitality (Gauslaa \& Solhaug 1999, 2000, Gauslaa et al. 2006, Larsson et al. 2014). These aspects can be exacerbated in potentially arid environments, such as the Mediterranean region, where beech and oak-dominated forests are the main habitats for Lobaria populations (Rubio-Salcedo et al. 2015). The impact of forestry on the abundance and fertility of $L$. pulmonaria populations has been assessed in boreal forests (Rolstad et al. 2001, Edman et al. 2008). Nevertheless, the impact of logging on $L$. pulmonaria populations in the Mediterranean region has not been clearly quantified (i.e., measured as biomass loss).

In March 2016, a large population of $L$. pulmonaria including hundreds of fertile thalli has been depleted and threatened by a legal logging for timber within a Mediterranean oak wood forest of central Italy. The damaged stand is a local hotspot for this model species. In this site, L. pulmonaria has a patchy distribution, colonizing several tree species (more than 1000 phorophytes): mostly Quercus ilex, Quercus cerris, Quercus pubescens, Arbutus unedo, Sorbus torminalis, Crataegus monogyna, Fraxinus ornus and even the bark of Hedera helix growing on these trees. Scattered thalli may also occur on fallen and standing deadwood and on soil-dwelling mosses. In fact, large stands with rich populations are core areas for several rare lichens and have conservation priority due to a higher genetic variability and evolutionary potential compared to small-sized stands (Ravera et al. 2006, Nascimbene et al. 2010). In parallel with the cutting, we saved as much fresh material as possible to be used for conservation and experimental purposes; we estimated the overall distribution of the population and quantified the loss of biomass and fertile thalli, whose development may require up to 35 years in forest habitats under stable ecological conditions (Scheidegger et al. 1997). We addressed the following questions: (i) which is the impact of logging on the model species within a Mediterranean mixed oak forest? (ii) do logging operations affect the vitality of the thalli growing on retained-isolated trees? Lastly, (iii) moving from local to broad-scale the study provides suggestions for the conservation of threatened macrolichens in Mediterranean oak forests and an overview on the status of L. pulmonaria (inclusion in red lists and legal protection) in Europe.

\section{Materials and methods}

Study site and experimental constraints The study was conceived in March 2016 as soon as we became aware of a legal logging for timber in a Mediterranean mixed oak forest stand of 4.4 ha in Tuscany, central Italy (Fig. 1), that was previously recognized as a local hotspot of L. pulmonaria (Paoli et al. 2013). The stand extends for about $500 \mathrm{~m}$ according with $\mathrm{E}-\mathrm{W}$ direction on a hillside with a $\mathrm{N}$ slope. In the area, oak wood forests are generally managed by a coppice system with standards and rotation cycles of about 18-20 years. However,

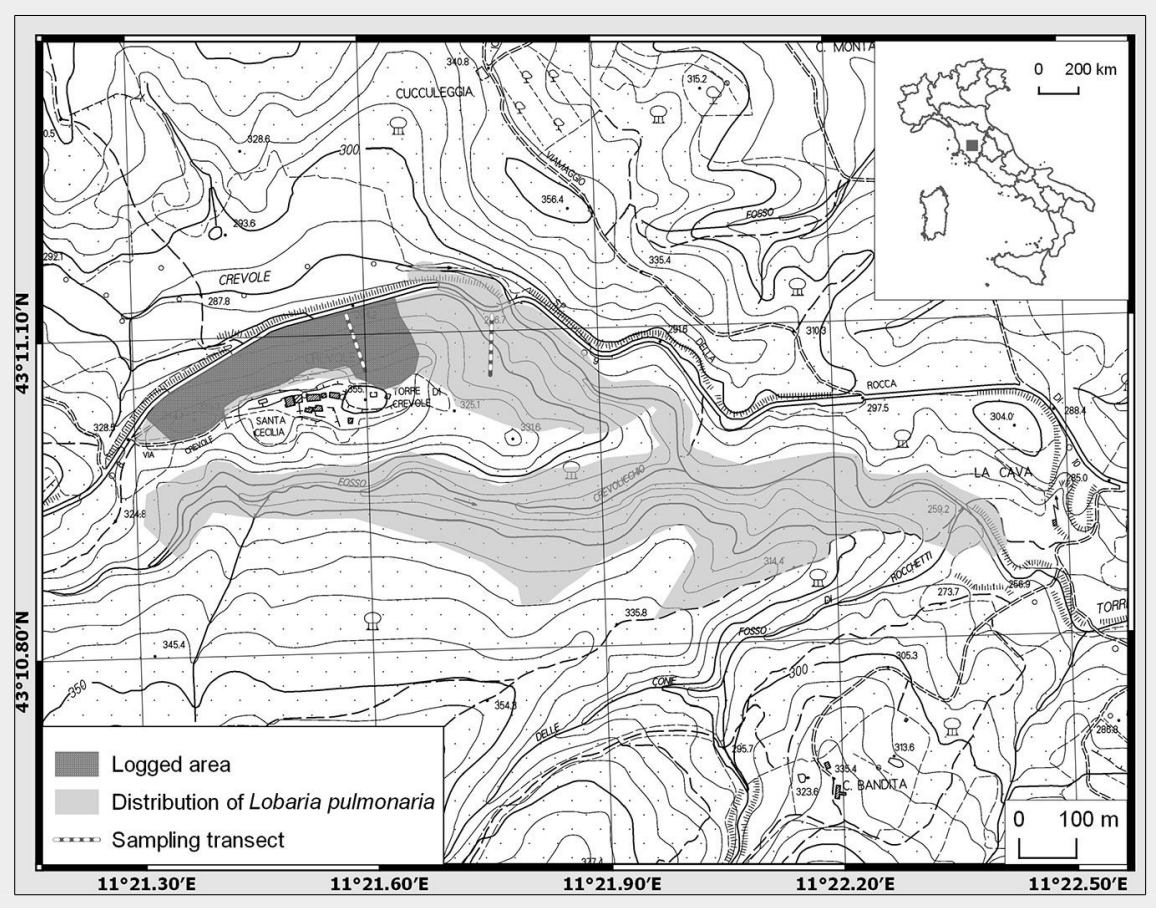

Fig. 1 - Map of the study area (Central Tuscany, Italy). some stands with low management intensity have a longer logging cycle, which dates back to more than 40 years ago, as in our case. Upon our request, local authorities temporarily suspended the cutting for a few days (about 1 ha of the stand was already cut at that moment). This interruption offered the opportunity to investigate in the field the damage occurred to forest macrolichens, with a focus on the model species. Thanks to the cooperation with local authorities and woodcutters, the subsequent logging activity was addressed to an uneven-aged coppice system, allowing the preservation of several trees with L. pulmonaria (hereafter Lobaria-trees) and also some patches (islands) with groups of uneven-aged trees (Fačkovcová et al. 2019). In order to assess the impact of logging, the logged stand was compared with an adjacent unlogged area by means of sampling transects (Fig. 1). Both sites are located along a narrow valley, with similar orientation $(\mathrm{N})$, soil type, tree age and composition, moisture and distance from the closest stream.

\section{Assessment of the loss of L. pulmonaria}

\section{Occurrence}

We estimated the occurrence of L. pulmonaria on the basis of a strip adaptive cluster sampling accounting for the spatial clustering of the lichen population (Thompson 1990, Philippi 2005, Turk \& Borkowski 2005). We surveyed 20 adjacent plots $(5 \times 5$ $\mathrm{m})$ along two randomly selected transects (Fig. 1), one being established in the logged stand and one in the neighbouring unlogged stand. When L. pulmonaria was found within a $5 \times 5 \mathrm{~m}$ quadrat, two secondary adjacent quadrats, at the eastern and western sides, were adaptively included into the transect.

Within each plot, we recorded the number of colonized and not colonized trees, the circumference of each individual tree, the number of $L$. pulmonaria thalli as well as their size and aspect on the trunk, and the presence of structures for vegetative and sexual reproduction. For practical reasons, measurements were gathered up to 2 $\mathrm{m}$ for all stems with $\mathrm{L}$. pulmonaria thalli. We also recorded the occurrence of additional epiphytic species of conservation concern (Nascimbene et al. 2013b). Nomenclature of lichens follows Nimis (2016).

\section{Biomass}

In order to link thallus size to biomass of L. pulmonaria, we assessed the relationship between lichen surface area $\left(\mathrm{cm}^{2}\right)$ and weight $(\mathrm{mg})$ based on 100 randomly selected air dried thalli. By means of this procedure we translated the estimated surfaces of the thalli into lichen biomass.

For an estimation of the potential loss of L. pulmonaria biomass in the field, three $100 \mathrm{~m}^{2}(10 \times 10 \mathrm{~m})$ plots were randomly selected in the core area (the first logged sector, extensively colonized): in each plot a 
group of four volunteers carefully collected for 30 minutes as much material as possible from the logged trees as well as from the ground. To check the collection efficiency, a secondary $4 \mathrm{~m}^{2}(2 \times 2 \mathrm{~m})$ plot was randomly selected within each $100 \mathrm{~m}^{2}$ plot and volunteers retrieved the remaining fragments of the thalli until all the material remained was removed from the plot. This step (limited in space and time, since it was carried out during the short interruption of logging operations) allowed an estimate of the overall biomass of $L$. pulmonaria within any randomly selected $100 \mathrm{~m}^{2}$ plot in the core area. Since these plots were mainly located within the first $25 \mathrm{~m}$ from the forest edge, for a better estimation of the biomass of $L$. pulmonaria over the whole area, in a second step we harvested fallen thalli and measured those still standing after the cutting also from 16 square plots $\left(4 \mathrm{~m}^{2}\right)$ located at intervals of $25 \mathrm{~m}$ over a regular grid with the origin randomly selected.

Assessment of the vitality of the thalli

During April 2016 and in May-June 2017 (after the conclusion of logging operations), the vitality of the macrolichen L. pulmonaria was assessed through the analysis of chlorophyll (Chl) a fluorescence emission, measuring the potential quantum yield of primary photochemistry $\left(F_{V} / F_{M}\right)$, where $F_{v}=\left(F_{m}-F_{0}\right)$ is the variable fluorescence and $F_{o}$ and $F_{m}$ are minimum and maximum $\mathrm{Chl} a$ fluorescence. In the field, thalli were kept hydrated (sprayed with mineral water) and dark adapted overnight (covered with a black velvet cloth) before the measurements. Thalli were then lightened for one second with a saturating (up to $3000 \mu \mathrm{mol}$ of photosynthetically active photons $\mathrm{m}^{-2} \mathrm{~s}^{-1}$ ) light pulse and fluorescence emission was recorded for one second. Measurements were carried out with a Plant Efficiency Analyzer fluorimeter (Handy PEA ${ }^{\circledast}$, Hansatech Ltd, Norfolk, UK) on thalli of $L$. pulmonaria preserved in the logged area, on those occurring in the adjacent unlogged area and on those retrieved from the ground. Up to 40 thalli were analyzed for each condition and 3-5 replicates were recorded on each thallus, according to its size, in order to minimize error estimates owing to intrathalline variability. Furthermore, we evaluated the condition of the thalli on the basis of signs of discoloration and bleaching and the presence of necrotic parts. Thalli were attributed to the categories of damaged (presence of diffused discoloration, necroses or holes between the ridges), variable (moderately damaged, with occasional discolorations or necroses), or healthy (no visual injury).

For the statistical analysis, the KruskalWallis non-parametric $\mathrm{H}$ test was used to detect differences in maximal PSII efficiency $(P<0.05)$, using the Dunn's test for post-hoc comparisons.

\section{Results}

\section{Impact of logging on occurrence and} biomass of L. pulmonaria

Forest logging reduced stem density from $\sim 1100$ to 165 stems ha $^{-1}$, with a consequent increase of sun irradiance on retained-isolated trees (from 130-1100 to 900$1550 \mu \mathrm{mol} \mathrm{s}^{-1} \mathrm{~m}^{-2}$ PAR - Tab. 1). Owing to the depletion of host trees, occurrence and biomass of $L$. pulmonaria were significantly reduced. Due to logging operations, along the logged transect, only $26 \%$ of the plots (9 out of 34) resulted colonized by L. pulmonaria (284 individuals over 14 trees - Q. cerris and Q. Ilex), 13 plots remained without host trees and 12 with Lobaria-free trees. On the other hand, along the unlogged transect, $45 \%$ of the plots (18 out of 40) were colonized (288 individuals over 50 trees) and all plots included a potential host tree (Q. pubescens, Q. cerris, Fraxinus ornus and Q. ilex, including stumps). Most of the thalli (75\%) in the logged stand were small and sterile, while the largest ones $(>26 \times 16 \mathrm{~cm})$ disappeared due to logging operations (Tab. 1). After cutting, the share of larger thalli with diaspores (vegetative and/or sexual) was $50 \%$ of the unlogged stand. In both cases, $75 \%$ of the colonized plots were located within the first $50 \mathrm{~m}$ from the forest margin, which hosted $84 \%$ of the overall lichen biomass. A previous study (Paoli et al. 2013) reported the presence of rare lichens sharing the same habitat with L. pulmonaria (namely, Fuscopannaria mediterranea, Gyalecta derivata, Megalaria laureri, Pannaria conoplea, Parmeliella triptophylla, Pectenia plumbea, Ricasolia amplissima). Later, also the rare macrolichen Lobarina scrobiculata, was found. After logging, only P. plumbea, L. scrobiculata and $R$. amplissima were recorded within the logged transect.

By measuring dimensions and weight of fragments and whole thalli of regular shape, the calculated surfaces of L. pulmonaria were converted into a biomass estimate of $15.2-19.8 \mathrm{mg} \mathrm{cm}^{-2}$ (95\% confidence interval). The combination of data on occurrence and biomass of the specimens allowed estimating the biomass of L. pulmonaria still standing in the logged area up to $2 \mathrm{~m}$ from the ground (ca. $7.3 \mathrm{~kg} \mathrm{ha}^{-1}$ ), which mainly consisted of sterile thalli (68\%). The same procedure applied to the unlogged stand allowed estimating an average biomass of $11.5 \mathrm{~kg} \mathrm{ha}^{-1}$, which largely consisted of thalli with vegetative diaspores (39\%) or also sexual structures (12\%). A comparison between thallus sizes (unlogged vs. logged stand) suggested that mainly larger thalli fell to the ground and hence were damaged. In fact, $60 \%$ of the samples saved from ground and bark of cut logs were fertile and (excluding thallus fragments) with dimensions (length or width) up to $40 \mathrm{~cm}$.

Before logging, the biomass of L. pulmonaria (estimated as described above) in the study area was $15.8-19.6 \mathrm{~kg} \mathrm{ha}^{-1}$ and plots in the highly colonized sector reached levels up to $1.8 \pm 0.1 \mathrm{~kg}$ every $100 \mathrm{~m}^{2}$. Once we subtracted the biomass still standing in the logged area $\left(7.3 \mathrm{~kg} \mathrm{ha}^{-1}\right)$, we evinced that $8.5-12.3 \mathrm{~kg} \mathrm{ha}^{-1}(22-57 \%$ of the initial biomass, with an average of $40 \%$ ) could have been lost due to forest cutting (37-54 $\mathrm{kg}$ over the whole area). Altogether, the collaboration with local authorities and a short field training of woodcutters allowed

Tab. 1 - Characteristics of the investigated oak forest, the sampling transects and the model species L. pulmonaria, comparing logged and unlogged stands. Dimension of the thalli: average length of larger and shorter diameters, in parenthesis the number of specimens. $(*)$ : tree clusters (islands) excluded; (**): according to Nascimbene et al. (2013b).

\begin{tabular}{|c|c|c|c|}
\hline Level & Parameters & Logged stand & Unlogged stand \\
\hline \multirow[t]{3}{*}{ Mixed oak forest } & Density of potential host trees* & $\sim 165$ stems ha $^{-1}$ & $\sim 1050$ stems ha $^{-1}$ \\
\hline & Solar radiation (at noon, sunny days) & $900-1550 \mu \mathrm{mol} \mathrm{s}^{-1} \mathrm{~m}^{-2}$ PAR & $130-1100 \mu \mathrm{mol} \mathrm{s}^{-1} \mathrm{~m}^{-2}$ PAR \\
\hline & L. pulmonaria biomass $(0-2 \mathrm{~m})$ & $\sim 7.3 \mathrm{~kg} \mathrm{ha}^{-1}$ & $\sim 11.5 \mathrm{~kg} \mathrm{ha}^{-1}$ \\
\hline \multirow[t]{4}{*}{ Sampling transects } & Plots colonized by L. pulmonaria & $26 \%$ & $45 \%$ \\
\hline & Host trees colonized along the transects & 14 stems & 50 stems \\
\hline & Host tree circumference & $14-148 \mathrm{~cm}$ & $8-88 \mathrm{~cm}$ \\
\hline & Other lichens of conservation concern ${ }^{* *}$ & 3 species & 8 species \\
\hline \multirow[t]{4}{*}{ Model species level } & L. pulmonaria specimens per transect & 284 & 288 \\
\hline & Sterile juvenile thalli & $6 \mathrm{~cm} \times 4 \mathrm{~cm} \mathrm{(213)}$ & $5 \mathrm{~cm} \times 3 \mathrm{~cm}(141)$ \\
\hline & Thalli with vegetative diaspores & $14 \mathrm{~cm} \times 9 \mathrm{~cm} \mathrm{(40)}$ & $13 \mathrm{~cm} \times 9 \mathrm{~cm}(112)$ \\
\hline & Fertile thalli with apothecia & $26 \mathrm{~cm} \times 16 \mathrm{~cm}(31)$ & $36 \mathrm{~cm} \times 23 \mathrm{~cm}(35)$ \\
\hline
\end{tabular}


Tab. 2 - Potential quantum yield of primary photochemistry $\left(F_{V} / F_{M}\right)$, as indicator of the vitality of the samples. Mean \pm standard deviation (SD) and $95 \%$ confidence interval $(95 \% \mathrm{Cl}) .(\mathrm{n})$ : Fluorescence measurements. Values followed by a different letter are significantly different $(P<0.05)$ after Dunn's test.

\begin{tabular}{lcccl}
\hline \multirow{2}{*}{ Lobaria pulmonaria } & \multirow{n}{*}{} & \multicolumn{2}{c}{$\mathrm{F}_{\mathrm{v}} / \mathrm{F}_{\mathrm{M}}$} & \multirow{2}{*}{ Conditions } \\
\cline { 3 - 4 } & & Mean $\pm \mathrm{SD}$ & $95 \% \mathrm{Cl}$ & \\
\hline $\begin{array}{l}\text { Thalli saved from the } \\
\text { logged area (2016) }\end{array}$ & 100 & $0.727 \pm 0.042^{\mathrm{a}}$ & $0.705-0.750$ & healthy \\
\hline $\begin{array}{l}\text { Logged area (2017) } \\
\text { Unlogged area (2017) }\end{array}$ & 100 & $0.539 \pm 0.117^{\mathrm{b}}$ & $0.476-0.601$ & variable \\
\hline
\end{tabular}

preserving a significant share of Lobaria trees ( $65 \%$ of the standing trees) and small fragments of forest with Lobaria-trees which could act as reservoir.

\section{Assessment of the vitality of L. pulmo-} naria

One year later (spring 2017), the thalli still growing on isolated-retained trees in the logged area showed visible symptoms of damage in $46 \%$ of Lobaria-trees, consisting in bronzing (melanisation), or in the worst case (14\%) discoloration, bleaching and curling of the thalli. The remaining fraction (54\% during spring 2017) still consisted of healthy thalli, with a dominant greenish colour and absence of discolorations and necrotic parts.

Kruskal-Wallis $\mathrm{H}$ test showed a statistically significant difference in maximal PSII efficiency between sites, $\chi^{2}(2, N=300)=$ 142.85, $\mathrm{P}<0.001$. One year after forest cut ting a significant decrease of the maximal PSIl efficiency of the lichen photobiont $\left(F_{v} / F_{M}\right)$ was observed in the thalli of the logged stand, when compared to those of the unlogged stand and to the thalli har vested (saved) from ground and cut logs in 2016. Overall, $F_{v} / F_{M}$ values were within the range $0.726-0.760$ ( $95 \%$ confidence interval) in the unlogged area and 0.476-0.601 in the logged area (Tab. 2).

\section{Discussion}

Impact of forest logging on L. pulmonaria

Forest logging significantly reduced the occurrence and biomass of L. pulmonaria within the managed stand, mainly due to the depletion of host trees. Rare species that shared the same habitat with L. pulmonaria (Paoli et al. 2013) were likely affected or lost after logging. Similarly, in Central Spain it was demonstrated that total species richness and in particular cyanolichens richness, were negatively affected by intensive forest management (Aragón et al. 2010). Noteworthy, in our study a comparable number of thalli of L. pulmonaria has been recorded both in the logged and the unlogged transects, suggesting that the logged stand was densely colonized, much more than the unlogged one. Our measurements revealed an average estimated loss of $40 \%$ of the lichen biomass and showed that L. pulmonaria thalli remained on retained-trees were those of smaller size and chiefly sterile due the loss of wider and fertile ones. Edman et al. (2008) estimated that after logging in a hardwood forest of Canada, the average abundance of $L$. pulmonaria per tree was five times higher in uncut stands than in cut stands; moreover, the reduction of suitable trees and, hence, the alteration of site quality, led to a significant decline of fertile thalli after 5-9 years.

Forest logging affected $L$. pulmonaria also indirectly, in particular increasing light influx to the thalli remained within the logged stand, leading to an overall decrease of their photosynthetic efficiency. This lichen, especially in the dry state, proved to be very sensitive to a high irradiance under laboratory conditions (Gauslaa \& Solhaug 1999). High-light-intensity damage to $L$. pulmonaria thalli has been reported also in field studies as a consequence of abrupt changes in light conditions (Gauslaa \& Solhaug 2000), such as after logging. In fact, long-term exposures under these conditions may produce visible symptoms of injury, such as bronzing and bleaching of the thalli (Gauslaa \& Solhaug 2000), similar to those observed in our study. In the Mediterranean region, higher light irradiance in oak forests during summer, together with the decoupling of moisture and light availability across an annual cycle, have been hypothesized to shorten the generation time of $L$. pulmonaria in oak woods compared to beech forests (RubioSalcedo et al. 2015).

Lobaria pulmonaria has been recognized as sensitive to the effects of logging and the consequent increase in habitat dryness even in boreal forests. A simulated logging carried out collecting L. pulmonaria thalli in old forests and transplanting them into clear-cuts showed that logging in winter was less harmful and could be associated to higher growth rates than logging in summer, which was associated with higher chlorophyll degradation and lower growth (Larsson et al. 2014). Furthermore, partial cuts better supported L. pulmonaria growth rather than clear-cuts (Coxson \& Stevenson 2007a, 2007b). Under a climate change scenario, L. pulmonaria could face a high extinction risk associated with a possible reduction of their distribution range
(Nascimbene et al. 2016). Therefore, any habitat modification that implies an increase of dry conditions would likely affect this sensitive species (and other associated cryptogams) much more than in the past.

\section{Practical suggestions for the conserva- tion of threatened macrolichens in Me- diterranean oak forests}

The conservation of epiphytic lichens depends on the understanding of the main factors influencing their distribution, abundance, dispersal, establishment, growth and reproduction (Benesperi et al. 2018). Lobaria pulmonaria is an indicator of valuable forest habitats (Nascimbene et al. 2010, 2013c) and important sites for the conservation of cryptogamic species belonging to understudied groups (e.g., bryophytes - Scheidegger \& Werth 2009, Brunialti et al. 2015). In our case, to mitigate further potential damages due to logging, several Lobaria-trees and patches (islands) with uneven-aged trees were preserved in the investigated stand (Fačkovcová et al. 2019), without a negative impact on the activity of woodcutters. Despite the fact that thalli on retained-isolated trees showed a lower vitality compared to the unlogged stand, they could still act as a source of propagules. Furthermore, specimens on retained-forest patches (islands) may represent a reservoir for future recolonizations.

An ecologically sustainable management should take into account that sensitive species with long generation cycles may not be able to recolonize available forest habitats if the sources of generative propagules have been depleted (Scheidegger \& Werth 2009, Hauck et al. 2013). In this perspective, retaining patches with colonized trees, sufficient moist microclimate (Sillett et al. 2000, Peterson \& McCune 2001, Werth et al. 2006) and a mixed selection of younger as well as older host trees could be effective practices for the conservation of rare epiphytic lichens (Schei et al. 2013). These considerations on suitable forest management practices should be extended also for the safeguard of other understudied taxa of forest cryptogams. The survival of $L$. pulmonaria is compatible with non-intensive forest management practices, provided that in managed stands a significant portion of Lobaria-trees is preserved (see Scheidegger et al. 2012 and references therein), that the extent of the disturbance is not wider than the dispersal ability of the species and that all successional stages persist and continuously occur after logging (Lindenmayer et al. 2000, Jüriado et al. 2011). Furthermore, forest clearings should be kept small to maintain a sufficiently moist microclimate (Werth et al. 2006) and strong interconnections between the stands (Nascimbene et al. 2013a, 2013C). These features are of outmost importance in potentially dry environments, such as Mediterranean oak forests. Moreover, populations with fertile individuals (as in our case) must be at a higher rank in 
terms of conservation priority, than strictly asexual populations.

Research results underline an international responsibility for the protection of forest habitats hosting sensitive species (Eaton \& Ellis 2014) and support the inclusion of Lobaria species within European conservation policies, such as the Habitat Directive. The current condition of $L$. pulmonaria (inclusion in red lists and legal protection) in most European countries has been summarized in Tab. S1 (Supplementary material). The lichen is generally redlisted, based on IUCN categories, in northern and central Europe (up to Russia) and in several countries of central Europe it is also legally protected. On the other hand, although widely declining, in Mediterranean countries the species has a lower level of implementation in conservation policies. Therefore, it has been highlighted the importance of encouraging stakeholders to identify and protect stands with high conservation priority that could act as sources of propagules to the surrounding environment (Nascimbene et al. 2013C). This is relevant especially in the case of unprotected forests. However, to prevent situations of damage (as the one described in this study), L. pulmonaria should be formally protected also in Mediterranean countries, at least ensuring the safeguard of those forest habitats hosting fertile populations.

\section{Conclusions}

Logging for timber in a Mediterranean mixed oak forest in central Italy depleted forest epiphytic cryptogams, including a large population of the macrolichen $L$. pulmonaria, red-listed in several European countries, but not in Italy. One year after logging operations, individuals on retainedisolated trees within the logged stand showed lower photosynthetic performances compared to those of the unlogged stand. Their vitality was significantly reduced. The study outlined specific issues for the conservation of macrolichens in Mediterranean forest ecosystems and the outmost importance of ensuring the safeguard of oak forest stands hosting fertile populations of $L$. pulmonaria in order to prevent unintended damages.

\section{Acknowledgements}

We are grateful to Elena Guerrini, Gabriele Sgroi, Tania Contardo (Italy) and Maya Thapa (Nepal) for helping with the lichen collection; to the students of the University of Florence for their help during field sampling; to Alessandro Ceppatelli and Mauro Pisaneschi (forest managers, "Unione dei Comuni della Val di Merse", Tuscany, Italy) for their professional support and sensitivity; to Michelle Abajian (USA) for language revision. We would like to thank Eugenios Agathokleous (Cyprus), Gintare Sujetoviene (Lithuania), Silvana Munzi and Paula Matos (Portugal), Luciana Zedda (Germany), Maja Maslać (Croatia),
Aino Hämäläinen (Finland), Polina Degtyarenko (Estonia), Martin Westberg (Sweden), Anna Fedosova (Russia), Jiří Malíček (Czech Republic) and László Lökös (Hungary) for information concerning the protection of Lobaria pulmonaria in Europe. We acknowledge two anonymous reviewers for their valuable comments on a first draft of the manuscript.

\section{Authors contribution}

$L P, R B, E B, A V, B A, L D N, M L, S L, M M, S R$ (investigation); ZF, AG, SL, SR, AL (information concerning the inclusion in red lists and legislations); LP, JN, SLo, SR, RB, ZF, AG (planning of the study, data analysis and elaboration, writing and reviewing of the manuscript); LP (coordinator).

\section{References}

Aragón G, Martínez I, Izquierdo P, Belinchón R, Escudero A (2010). Effects of forest management on epiphytic lichen diversity in Mediterranean forests. Applied Vegetation Science 13: 183-194. - doi: 10.1111/j.1654-109X.2009.01060.x

Benesperi R, Nascimbene J, Lazzaro L, Bianchi E, Tepsich A, Longinotti S, Giordani P (2018). Successful conservation of the endangered forest lichen Lobaria pulmonaria requires knowledge of fine-scale population structure. Fungal Ecology 33: 65-71. - doi: 10.1016/j.funeco.2018.01.006 Bergamini A, Scheidegger C, Stofer S, Carvalho P, Davey S, Dietrich M, Dubs F, Farkas E, Groner U, Kärkkäinen K, Keller C, Lökös L, Lommi S, Máguas C, Mitchell R, Pinho P, Rico VJ, Aragón G, Truscott AM, Wolseley PA, Watt A (2005). Performance of macrolichens and lichen genera as indicators of lichen species richness and composition. Conservation Biology 19: 10511062. - doi: 10.1111/j.1523-1739.2005.00086.x

Brunialti G, Frati L, Ravera S (2015). Structural variables drive the distribution of the sensitive lichen Lobaria pulmonaria in Mediterranean oldgrowth forests. Ecological Indicators 53: 37-42. doi: 10.1016/j.ecolind.2015.01.023

Campbell J, Fredeen AL (2004). Lobaria pulmonaria abundance as an indicator of macrolichen diversity in Interior Cedar-Hemlock forests of east-central British Columbia. Canadian Journal of Botany 82: 970-982. - doi: 10.1139/ b04-074

Coxson DS, Stevenson SK (2007a). Growth rate responses of Lobaria pulmonaria to canopy structure in even-aged and old-growth cedarhemlock forests of central-interior British Columbia, Canada. Forest Ecology and Management 242: 5-16. - doi: 10.1016/j.foreco.2007.01. 031

Coxson DS, Stevenson SK (2007b). Influence of high-contrast and low-contrast forest edges on growth rates of Lobaria pulmonaria in the inland rainforest, British Columbia. Forest Ecology and Management 253: 103-111. - doi: 10.1016/ j.foreco.2007.07.008

Eaton S, Ellis CJ (2014). High demographic rates of the model epiphyte Lobaria pulmonaria in an oceanic hazelwood (western Scotland). Fungal Ecology 11: 60-70. - doi: 10.1016/j.funeco.2014. 03.007

Edman M, Eriksson AM, Villard MA (2008). Effects of selection cutting on the abundance and fertility of indicator lichens Lobaria pulmonaria and Lobaria quercizans. Journal of Applied Ecology 45: 26-33. - doi: 10.1111/j.1365-26 64.2007.01354.x

Fačkovcová Z, Guttová A, Benesperi R, Loppi S, Bellini E, Sanità di Toppi L, Paoli L (2019). Retaining unlogged patches in Mediterranean oak forests may preserve threatened forest macrolichens. iForest 12: 187-192. - doi: 10.3832/ifor29 17-012

Gauslaa Y, Solhaug KA (1999). High-light damage in air-dry thalli of the old forest lichen Lobaria pulmonaria interactions of irradiance, exposure duration and high temperature. Journal of Experimental Botany 50: 697-705. - doi: 10.1006/ lich.1999.0265

Gauslaa Y, Solhaug KA (2000). High-light-intensity damage to the foliose lichen Lobaria pulmonaria within a natural forest: the applicability of chlorophyll fluorescence methods. The Lichenologist 32: 271-289. - doi: 10.1006/lich.19 99.0265

Gauslaa Y, Lie M, Solhaug K, Ohlson M (2006). Growth and ecophysiological acclimation of the foliose lichen Lobaria pulmonaria in forests with contrasting light climates. Oecologia 147: 406416. - doi: 10.1007/s00442-005-0283-1

Hauck M, De Bruyn U, Leuschner C (2013). Dramatic diversity losses in epiphytic lichens in temperate broad-leaved forests during the last 150 years. Biological Conservation 157: 136-145. doi: 10.1016/j.biocon.2012.06.015

Jüriado I, Liira J, Csencsics D, Widmer I, Adolf C, Kohv K, Scheidegger C (2011). Dispersal ecology of the endangered woodland lichen Lobaria pulmonaria in managed hemiboreal forest landscape. Biodiversity and Conservation 20: 18031819. - doi: 10.1007/s10531-011-0062-8

Kraus D, Krumm F (2013). Integrative approaches as an opportunity for the conservation of forest biodiversity. European Forest Institute, Germany, pp. 284.

Krause J, Wagner HG, Otte V (2017). Rote Liste und Gesamtartenliste der Flechten (Lichenes) von Berlin [Red list and species list of lichens of Berlin]. In: "Derlandesbeauftragte Für Naturschutz und Landschaftspflege / Senatsverwaltung für Umwelt, Verkehr und Klimaschutz (Hrsg.)" [Regional supervisor for nature and landscape / Senate management for environment, transport and climate protection]. Rote Listen der gefährdeten Pflanzen, Pilze und Tiere von Berlin [Red Lists of Endangered Plants, Fungi and Animals of Berlin], $28 \mathrm{~S}$. DepositOnce, Web site. [in German] - doi: 10.14279/depositonce-5841

Larsson P, Solhaug KA, Gauslaa Y (2014). Winter the optimal logging season to sustain growth and performance of retained epiphytic lichens in boreal forests. Biological Conservation 180: 108-114. - doi: 10.1016/j.biocon.2014.09.045 Lettau G (1912). Beiträge zur Lichenographie von Thüringen [Contributions to the Lichenography of Thuringia]. Hedwigia 51: 176-220. [in German] Lindenmayer DB, Margules CR, Botkin DB (2000). Indicators of biodiversity for ecologically sustainable forest management. Conservation Biology 14: 941-950. - doi: 10.1046/j.15231739.2000.98533.x

Nadyeina O, Dymytrova L, Naumovych A, Postoyalkin S, Scheidegger C (2014). Distribution and 
dispersal ecology of Lobaria pulmonaria in the largest primeval beech forest of Europe. Biodiversity and Conservation 23: 3241-3262. - doi: 10.1007/s10531-014-0778-3

Nascimbene J, Brunialti G, Ravera S, Frati L, Caniglia G (2010). Testing Lobaria pulmonaria (L.) Hoffm. as an indicator of lichen conservation importance of Italian forests. Ecological Indicators 10: 353-360. - doi: 10.1016/j.ecolind.2009. 06.013

Nascimbene J, Thor G, Nimis PL (2013a). Effects of forest management on epiphytic lichens in temperate deciduous forests of Europe - a review. Forest Ecology and Management 298: 2738. - doi: 10.1016/j.foreco.2013.03.008

Nascimbene J, Nimis PL, Ravera S (2013b). Evaluating the conservation status of epiphytic lichens of Italy: a red list. Plant Biosystems 147: 898-904. - doi: 10.1080/11263504.2012.748101 Nascimbene J, Ylisirniö AL, Pykälä J, Giordani P (2013C). Lichens: sensitive indicators of changes in forest environment. In: "Integrative Approaches as an Opportunity for the Conservation of Forest Biodiversity" (Kraus D, Krumm F eds). European Forest Institute, Freiburg, Germany, pp. 180-185. [online] URL: http://www. researchgate.net/publication/259757410

Nascimbene J, Casazza G, Benesperi R, Catalano I, Cataldo D, Grillo M, Isocrono D, Matteucci E, Ongaro S, Potenza G, Puntillo D, Ravera S, Zedda L, Giordani P (2016). Climate change fosters the decline of epiphytic Lobaria species in Italy. Biological Conservation 201: 377-384. - doi: 10.1016/j.biocon.2016.08.003

Nimis PL (2016). The lichens of Italy. A second annotated catalogue. EUT, Trieste, Italy, pp. 739. [online] URL: http://www.openstarts.unit s.it/handle/10077/21022

Ockinger E, Niklasson M, Nilsson SG (2005). Is local distribution of the epiphytic lichen Lobaria pulmonaria limited by dispersal capacity or habitat quality? Biodiversity and Conservation 14: 759-773. - doi: 10.1007/s10531-004-4535-x Otálora MG, Martínez I, Belinchón R, Widmer I, Aragón G, Escudero A, Scheidegger C (2011). Remnants fragments preserve genetic diversity of the old forest lichen Lobaria pulmonaria in a fragmented Mediterranean mountain forest. Biodiversity and Conservation 20: 1239-1254. doi: 10.1007/s10531-011-0025-0
Paoli L, Guttová A, Anselmi B (2013). Osservazioni sui licheni di Crevole [Observations on the lichens of Crevole]. MurloCultura 16 (1): 8-10. [in Italian]

Peterson EB, McCune B (2001). Diversity and succession of epiphytic macrolichen communities in low-elevation managed conifer forests in Western Oregon. Journal of Vegetation Science 12: 511-524. - doi: 10.2307/3237003

Philippi T (2005). Adaptive cluster sampling for estimation of abundances within local populations of low abundances plants. Ecology 86: 1091-1100. - doi: 10.1890/04-0621

Ravera S, Massari G, Genovesi V (2006). Phytoclimatic characterization of lichen habitats in central Italy. Nova Hedwigia 82: 143-165. - doi: 10.1127/0029-5035/2006/0082-0143

Rose F (1976). Lichenological indicators of age and environmental continuity in woodlands. In: "Lichenology: Progress and Problems" (Brown DH, Hawksworth DL, Bailey RH eds). Academic Press, London, UK, pp. 279-307.

Rolstad J, Gjerde I, Storaunet KO, Rolstad E (2001). Epiphytic lichens in Norwegian coastal spruce forest: historic logging and present forest structure. Ecological Applications 11: 421436. - doi: 10.1890/1051-0761(2001)011[0421:ELIN CS]2.0.CO;2

Rubio-Salcedo M, Merinero S, Martínez I (2015). Tree species and microhabitat influence the population structure of the epiphytic lichen Lobaria pulmonaria. Fungal Ecology 18: 1-9. - doi: 10.1016/j.funeco.2015.08.002

Schei FH, Blom HH, Gjerde I, Grytnes JA, Heegaard E (2013). Conservation of epiphytes: single large or several small host trees? Biological Conservation 168: 144-151. - doi: 10.1016/j.bioco n.2013.10.001

Scheidegger C, Flachsmann S, Zoller S, Frey B (1997). Naturschutzbiologie bei Flechten: Konzepte und Projekte [Conservation biology in lichens: concepts and projects]. Kleine Senckenbergische Reihe 27: 167-175. [in German]

Scheidegger C, Clerc P, Dietrich M, Frei M, Groner U, Keller C, Stofer S, Vust M (2002). Lista Rossa delle specie minacciate in Svizzera. Licheni epifiti e terricoli. Ambiente - Esecuzione [Red list of threatened species in Switzerland. Epiphytic and soil lichens. Environment - Execution]. UFAFP, Berne and WSL, Birmensdorf,
Switzerland, pp. 122. [in Italian]

Scheidegger C, Werth S (2009). Conservation strategies for lichens: insights from population biology. Fungal Biology Reviews 23: 55-66. - doi: 10.1016/j.fbr.2009.10.003

Scheidegger C, Bilovitz PO, Werth S, Widmer I, Mayrhofer H (2012). Hitchhiking with forests: population genetics of the epiphytic lichen Lobaria pulmonaria in primeval and managed forests in southeastern Europe. Ecology and Evolution 2: 2223-2240. - doi: 10.1002/ece3.341

Sillett SC, McCune B, Peck JE, Rambo TR, Ruchty A (2000). Dispersal limitations of epiphytic lichens result in species dependent on oldgrowth forests. Ecological Applications 10: 789799. - doi: 10.1890/1051-0761(2000)010[0789: DLOELR]2.0.CO;2

Sitzia T, Campagnaro T, Dainese M, Cassol M, Dal Cortivo M, Gatti E, Padovan F, Sommacal M, Nascimbene J (2017). Contrasting multi-taxa diversity patterns between abandoned and nonintensively managed forests in the southern Dolomites. iForest 10: $845-850$. - doi: $10.3832 /$ ifor2181-010

Thompson SK (1990). Adaptive cluster sampling. Journal of the American Statistical Association 85 (412): 1050-1059. - doi: 10.1080/01621459.19 90.10474975

Turk P, Borkowski JJ (2005). A review of adaptive cluster sampling: 1990-2003. Environmental and Ecological Statistics 12: 55-94. - doi: 10.1007/s10651-005-6818-0

Werth S, Wagner HH, Holderegger R, Kalwij JM, Scheidegger C (2006). Effect of disturbances on the genetic diversity of an old-forest associated lichen. Molecular Ecology 15: 911-921. - doi: 10.1111/j.1365-294X.2006.02838.x

Whittet R, Ellis CJ (2013). Critical tests for lichen indicators of woodland ecological continuity. Biological Conservation 168: 19-23. - doi: 10.101 6/j.biocon.2013.09.011

\section{Supplementary material}

Tab. S1 - Present status of Lobaria pulmonaria in several European countries and Russia: red list category and legal protection (if any).

Link: Paoli_2951@supploo1.pdf 